HOW Journal

Volume 27, Number 1, pages 83-104

https://doi.org/10.19183/how.27.1.505

HOW

\title{
Digital Storytelling: Boosting Literacy Practices in Students at A1-Level
}

\author{
Historias digitales: fomentando prácticas de alfabetización \\ en estudiantes de nivel A1
}

González Mesa, Pedro Alejandro'

\begin{abstract}
This article describes the implementation of digital storytelling in an English language class of eleventh graders at a private school in Mosquera, Colombia. It is a descriptive qualitative study, carried out for about six months by using digital tools to foster language production in the language learners. The implementation contained digital storytelling as a pedagogical strategy for developing the writing literacy practice. The personal stories and media literacy allowed the participants to combine both narratives and digital elements when writing in English in a collaborative work-group in which they co-constructed their stories. The data collected was analyzed by using ATLAS ti. Open questions looked for information about the writing process and the digital tools implemented when creating the stories. The findings revealed that the participants developed writing and speaking manners while assuming different roles. In addition, the digitalization of stories strengthened their multi-literacies. The participants' recordings of their voices helped them improve their oral production without worrying about their classmates' opinion. Finally, negotiation in the group roles, as writer, designer and media creator, played an important role when working in groups.

Keywords: collaborative learning, digital storytelling, digital tools, EFL, literacy practices, speaking, writing.

Pedro Alejandro González Mesa holds a Master's degree in Applied Linguistics to TEFL and has taught

English and trained teachers for more than 10 years. He currently works at Corporación Universitaria

Minuto de Dios, Bogotá, Colombia. His research interests include critical discourse analysis and

contextualized practices. pedro.gonzalez@uniminuto.edu

https://orcid.org/0000-0001-5882-5871

Received: January 10th, 2019. Accepted: September 3rd, 2019

This article is licensed under a Creative Commons Attribution-Non-Commercial-No-Derivatives 4.0 International License. License Deed can be consulted at https://creativecommons.org/licenses/by-ncnd $/ 4.0 /$
\end{abstract}




\section{Resumen}

El presente artículo evidencia los resultados de un proyecto de investigación desarrollado en un colegio privado del municipio de Mosquera (Colombia) en el que los estudiantes de grado once fueron los participantes. El estudio cualitativo descriptivo tomó seis meses de implementación y tuvo como base el uso de herramientas digitales para fomentar el aprendizaje del inglés como lengua extranjera. Se utilizó la creación de historias digitales como la herramienta pedagógica para desarrollar su competencia literaria en escritura; esto se debió a que esta herramienta permitía a los estudiantes combinar la narrativa con la tecnología en un idioma extranjero. Además de las ventajas ya mencionadas, se debe decir que los estudiantes trabajaron en grupo en la construcción de historias. Los instrumentos utilizados para la recolección de datos fueron documentos, entrevistas y productos de los estudiantes. Los resultados de la investigación revelan que los participantes desarrollaron las habilidades de escritura y producción oral de una manera colaborativa. El investigador creó preguntas abiertas con la finalidad de obtener información acerca del proceso de escritura y el uso de las herramientas digitales. Luego de la recolección de la información, esta fue analizada en el programa ATLAS ti y los resultados muestran que los estudiantes, al crear historias digitales, mejoraron sus competencias lectoescritoras multimodales, y al grabar sus voces mejoraron su producción oral y confianza. Finalmente, es importante mencionar que la toma de decisiones en conjunto es clave para este trabajo en términos de los roles que cada uno cumplía, como el que escribía la historia, el que diseñaba y el que finalmente le agregaba lo audiovisual.

Palabras clave: aprendizaje colaborativo, historias digitales, herramientas digitales, inglés como lengua extranjera, prácticas de alfabetización, oralidad, escritura.

\section{Introduction}

This study shows the way literacy practices can be boosted when writing digital stories. As a language teacher, I have faced different challenges when teaching English as a foreign language to students in high school, especially when trying to guide them in both writing and speaking processes. As a result, I realized that some of my students had difficulties when writing and speaking in English not only in face to face interactions but also in virtual environments such as Facebook. Therefore, I decided to carry out a research study to look for new alternatives to use information and communications technologies (here after ICTs) to help students express their ideas and opinions in English.

On the one hand, the students were lacking coherence and cohesion when developing tasks related to writing skills because they were not able to express their ideas without using a translator or the teacher's help. In addition, the pieces of evidence gathered in an online written activity showed that the students' written texts faced issues in terms of coherence and cohesion. For example, some of them had problems using the subject pronouns, or they were using translating programs instead of relying on their own writing process. Despite this, the students were interested in developing face to face or virtual writing and speaking activities, such as posting comments on social webs or carrying out voice recordings and 
videos to be posted on those virtual environments too. Finally, I could notice that the students felt more comfortable when working in groups in a collaborative manner, because they felt confident with their classmates to develop parts of the activities rather than working alone on the whole activity.

Therefore, the study that this article presents focuses on literacy practices, writing, and digital storytelling. A local researcher such as Lopez (2011) has looked for digital literacy practices with a project in which students created blogs. She found that,

Students increased their practical knowledge [...] by using multiple literacies to express in a new way of writing: blogging. Moreover, students communicate not only through a written language, but also through a visual one which include photos, images and videos. That helped them to increase and complement the meaning of their texts" (p. 67).

Lopez (2011) says that the social situated practices were, basically, a real fact in the project in the sense that students' interactions in the classroom were a reason to promote the spoken and written foreign language as a means of communication with the reader. Therefore, local studies remark on the digital literacy as a way that may improve some social and individual practices. It can be concluded that learners may foster communication by using visual aids when blogging. In Lopez's study, the students received help by images and videos in their blogs to understand better what the topic was about.

Additionally, Valderrama (2012) found that, in online literacies, learners create "a socially constructed meaning to the online community" (p. 78). They construct meaning based on social interactions when creating dialogues and scripts. He also found that "Students tend to perceive the activities proposed in the online community as a valuable opportunity to put their English into practice” (p. 78). Thus, my study looks for students to put language into practice when using digital tools to create stories, by providing them an opportunity to use a different environment from the classroom.

Others as Myers and Beach (2004) state that using ICTs in the classroom has become not only an opportunity to boost language learning but also a way to build up community practices (p. 257). Then, when putting together literacies and ICTs, learners have the possibility to be motivated and engaged in learning a language.

For this study, writing and ICTs are joined to improve language learning. To be more specific, writing practices have not been changed as Cross (2007) notes: "A hundred years ago modern languages were taught in the same way as the classics, through the written translation of texts" (p. 268). Cross (2007) also affirms that "writing is the least used skill" (p. 268) because it implies not only knowledge about a language but also multiple and dynamic facts that end in a textual composition. Complementarily, Prada (2011) states that "writing from a communicative perspective is seen [...] as the textual composition for issues of real 
life for a real audience, the act of writing being one that emerges from reading, decoding, and understanding an authentic text" (p. 11). In the same line, Rojas (2011) affirms that "writing (as in not copying), requires thinking, understanding, interpreting" (p. 13). Considering those authors, writing is a process in which the author must involve the reader, digital stories, and multimodal texts such as images, sounds, and videos.

The terms literacy practices, ICTs, and writing process help introduce the term digital storytelling. In that respect, Bayon et al. (2003) propose that "storytelling can benefit children in multiple, diverse ways which support academic success. Storytelling facilitates the recall of content/facts, assists in comprehension, and contributes to listening and concentration skills. Storytelling offers an opportunity for creative/artistic expression" (p. 54). This means that digital environments will be useful not only for learning a language but also for face to face interactions in classroom in which students' voices and stories can be presented by themselves in a free manner as an excuse to mediate between the creative/ artistic expression (developing the digital stories) and language learning. In their research study, Malkawi and Davies (2012) conclude that, "As a result of the research undertaken it has been identified that the use of multimedia technologies in the learning process have recently been included as a method of improving students' reflective skills" (p. 2). Besides the fact of increasing those reflective skills, these authors highlight the importance of workgroups when creating and writing digital stories because students "re-tell" stories to their classmates to provide linguistic and content feedback.

Similarly, Aguirre (2010) defends the benefits of group work when writing by stating that writing is not an isolated practice. That is why collaborative learning plays a crucial role for my study because it shows the way students negotiate not only meaning but also the roles they have when writing. Accordingly, Rojas (2011) affirms that, "The students are not only passive recipients of knowledge, but creators of their own mechanisms for working, sometimes self-directed and sometimes working collaboratively" (p. 12).

\section{Conceptual Framework}

Literacy practices. These are all the textual productions and interpretations given by a person or a group of people; hence, they are everywhere and are performed by community members all the time. Myers and Beach (2004) say that a literacy practice is a communicative practice which involves multiple interactions between the members of a community (p. 262). The implications are for teachers that care more for the linguistic aspect of the language, rather than the way people interact; they have to promote the use of the language in a given context instead of teaching the language as an isolated element of human communication, as happens in social networks where interaction becomes an interesting environment to work on literacy practices. Besides, Myers (2006) emphasizes the idea that teachers must work with 
digital elements to boost literacy practices in the classroom. In the author's words, "literacy and learning [...] [have] the greatest potential for grounding our work as English teachers and our integration of digital tools and multimodal representations is the conception of literacy as multiple socially constructed practices" (p. 62).

This concept has been changing through time, from pictorial representations to alphabetical vocabulary (Crystal, 2010, p. 46). White and Arndt (1991) affirm that writing is the ability to "transcend time and space, that makes teaching and learning of writing such an important experience" (p. 1). They also state that writing is an ability that allows expressing ideas, feelings, and insights in order to convince or inform people. In that sense, the purpose of writing is to convince or to inform a reader. When people write, they can create different and varied types of texts according to their intention. For White and Arndt (1991), writing is about words that represent a mental process which "demands conscious intellectual effort" (p. 3).

Media literacy. Nowadays, the big challenges for researchers have been the new literacies developed in virtual environments and for teachers the attention that they need to pay to the new generations of learners with respect to the way they address ICTs for reading and writing. In that sense, Kellner and Share (2005) define literacy as "the faculty to acquire reading, listening, writing, and speaking competences to comprehend and communicate with the world around us" (p. 369). Thus, literacy is a situated practice in which members of a community do varied activities for communicating, creating social relationships and systems of values, and identities (Myers \& Beach, 2004, p. 257).

In the same line of thought, it is necessary to talk about traditional media as newspapers, books, television, and new media, such as videos, podcasts, websites, and social networks because they are concepts that together with literacy and media literacy share certain similarities in language terms; for example, the use of written and spoken forms and the language itself as a means of communication. Perhaps the most remarkable difference would be the channel or the environment in which the communication takes place. For instance, Asthana (2008) claims that "the media world is a world where powerful images, words and sounds create reality" (p. 130). By comparing this definition with Kellner and Share's (2005, p. 371 ), the deduction is that one precedes the other by modifying, somehow, the environment where interactions are developed.

Additionally, Kellner (as cited in Alvermann \& Hagood, 2000, p. 194) considers media literacy to have serious implications in the development of literacy practices, due to the possibilities it presents to the users. He points out that "our culture is a media culture." In addition, he states that media is the primary vehicle for the distribution and dissemination of culture and it has supplanted previous modes of culture like the book or spoken word. As a 
result of this media invasion, new educators' proposals have combined literacy, writing, and media literacy. One of these proposals is digital storytelling.

Digital storytelling. Storytelling comes from the need of humans to express their thoughts and their vision about the world around them. Ancient people used to paint hieroglyphs, with which they showed and told stories about animals and customs (Malkawi \& Davies, 2012, p. 4). Those traditions changed when people and cultures developed more complex sounds and elaborated languages. Then, they started to transmit those stories in an oral way. Later, advantages in printing and writing forms allowed humans to write down their beliefs, thoughts, and ideas. Nowadays, with digital tools, there is an increasing era of digital stories, which fluctuate according to storytellers' needs.

Kenny (2008) describes the (or some) pedagogical implications of digital storytelling. He suggests that, "Digital students need to be taught literacy skills through more creative and diverse pedagogical instructional strategies" (p. 4). Therefore, digital storytelling is a tool for creating environments where learners can open their mind to new ways of expression while learning a foreign language. Besides the fact of increasing those reflective skills, Kenny states the importance of using workgroups within digital storytelling; he says that learners' activities of creating scripts and taking decisions in groups are important for their language learning.

To sum up, digital storytelling is a strategy that improves teaching and learning practices and an excuse for using virtual environments to empower students to create and use technologies as a medium and the language as a vehicle for second language learning. Czarnecki (2009) mentions that as students will gain new information and literacy skills through digital storytelling, then, those communication skills will be studied and fostered by teachers (p. 8).

Collaborative learning. These previous ideas are complemented by the concept of collaborative learning. Bruffe (1984) states that "The primary aim of collaborative learning [...] is to help students test the quality and value of what they know by trying to make sense of it to other people like themselves-their peers" (p. 640). Therefore, the goal of collaborative work is to make learners aware of peer-working benefits in the sense that they can be part of a group by contributing what they have previously learnt. Complementarily, Alavi (1994) draws attention to the development of the roles in collaborative learning saying that "Team members can monitor individual thinking, opinions, and beliefs and provide feedback for clarification and change" (p. 161). Then, the aim of collaborative work is not just to collaborate but also to create and boost other abilities that help the teaching-learning process among students.

One branch that has garnered the attention of different authors is online collaborative learning. According to Mei and Griffith (2014), "Online collaborative learning environments 
can have cognitive, sociocultural, and psychological advantages, including enhancing writing skills, critical thinking skills, and knowledge construction, while increasing participation, interaction, motivation, and reducing anxiety" (p. 303). These authors support the idea of creating activities that engage both virtual environments and collaborative work to help learners build up their confidence and strengthen cognitive and practical stills.

\section{Methodology}

A descriptive qualitative research study was selected. According to Vaismoradi (2013),

"The value of qualitative description lies not only in the knowledge that can originate from it, but also because it is a vehicle for presenting and treating research methods as living entities that resist simple classification and can result in establishing meaning and solid findings" (p. 399).

My study was based on the creation of stories in a collaborative manner. Those stories were also digitalized so that the manner in which this process fostered literacy practices was described. Additionally, this study implements a qualitative research approach because it is seen from the participants' perspective, taking into consideration the collaborative work developed by the students along the project (Creswell, 2014, p. 18). Thus, it seeks the literacy practices that the participating students gain when writing digital stories during English language classes.

Participants and sampling. The participating students were 48 eleventh graders whose English language proficiency level may be equal to the A1 level of the CEFR; they were selected from a classroom where I was the English language teacher. The students were from 14 to 16 years old. This sampling is known as a natural setting because of the interaction that I, as a teacher researcher, had with my students over the time and space (Creswell, 2014, p. 175). Although the institution is in Mosquera, most learners lived in Bogota; others were from other small towns around Mosquera. The participants were selected by using convenient sampling of the students who were previously assigned to the teacher-researcher that year. According to Nisha (2012), "in convenience sampling, subjects are included in the study because they happened to be in the right place at the right time" (p. 5).

Setting. This project took place at a private school located in Mosquera, a town close to the Colombian capital Bogota. The school offers technical education in which its students take English language classes six hours weekly. When the project was implemented, participating students had both the requested textbook and workbook. Subsequently, the language course topics and themes were based on these books; language teachers followed the scope and sequence proposed in these two books. A preliminary exam on English as a foreign language is not a requirement for students' admission to the institution. Therefore, 
the students' English language proficiency level was assorted. When developing this project, the participating students were asked to take their electronic devices, as smartphones and laptops, into the classroom. In addition, for the project the school provided an exclusive internet connection for the English language area.

The implementation had three pedagogical objectives: (1) to enable students to write stories, (2) to allow them to work in a collaborative way, and (3) to foster the students' literacy practices. The implementation was composed of seven different stages, named as (1) Getting ready to start, (2) introducing stories, (3) story stimulus, (4) story circle peer to peer story creation, (5) technical lessons, (6) technical work sessions, and (7) peer evaluations. The implementation took about three months and a half by having English language sessions of six hours per week. The content stages took about two to three weeks for their implementation. Two stories were created along the implementation. Face-to-face interactions and computer-mediated sessions were at the school where the creative and productive stages were done.

Data collection instruments and procedures. Three instruments were used to gather data. The first was document data. It refers to special personal documents on which the students wrote their thoughts and insights about the intended learning process. In addition, they wrote about their beliefs and perceptions before and after the implementation. There were two written pieces collected per participant, and in each I had the opportunity to manage the "language and the words of the participants" (Creswell, 2014, p. 181). Because the first piece collected was the first story draft, that document had multiple issues in terms of structure, language, accuracy and content that all helped me to take decisions before the students created the second and final story. The second piece was collected at the end of the project; this piece provided qualitative information about the whole writing and digital process of the stories.

The second instrument was a collection of digital stories. Creswell (2014) names those as "qualitative audio and visual materials" (p. 182). He states that this is an instrument that can be used to loudly extract the reality. Digital stories were helpful for collecting information to attain the research objective of identifying the literacy practices fostered.

The third instrument was interviews, with open-ended questions, which allowed (1) keeping track of the process that the students followed when creating the stories and of their strengths and weaknesses when doing so; and (2) accounting for the collaborative work and the literacy practices that the students developed when creating the digital stories. Interviews were a valuable instrument in this study because they helped control the students' line of development within the study (Creswell, 2014, p. 182). We also share Lankshear and Knobel's view (2004) of open-ended questionnaires when they affirm that these are "useful for identifying trends or preferences across a large number of people" (p. 36). For this study, 
two interviews were used. The first asked about the digital practices that the students had engaged in during the implementation; the second questioned the students about the process that they carried out in terms of design, group work, and literacy practices when creating the digital stories.

\section{Data Analysis and Resullts}

ATLAS.ti 5.2 software was used to organize, select, and work on the information collected and to organize the understanding and coding of the data. Open and axial coding were used to build the categories and subcategories presented in this section of the manuscript. From the data gathered, three categories emerged which describe the development of the digital stories and how it fitted with the idea of showing how literacies were boosted through the implementation of digital story-telling.

Figure 1 below shows the correlated categories and the connection as regards writing a digital story, literacy practices, learning awareness, and collaborative writing.

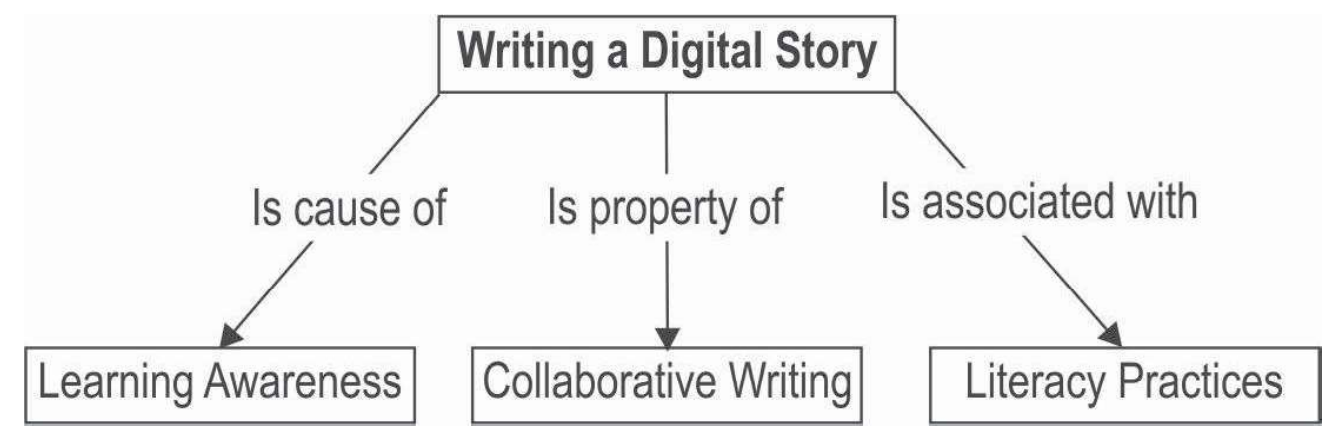

Figure 1. Writing a digital story.

A number of sub-categories belong to each of these three main categories. The subcategories describe the writing process when creating a digital story in an ampler manner. "Collaborative writing" is the most robust category from the analysis.

Category 1, Collaborative writing. This describes the way learners were able to work as a group for producing a written piece. Figure 2 below shows the collaborative work carried out by learners along the whole process. Codes that complement this construct are: students' initial ideas when creating a story; students' authoring skills; students' collective thinking on the reader engagement and students' collaboration traces. As a result of this category we can find most of the writing foundations implemented by the students at the beginning, in the middle and in the end processes. 


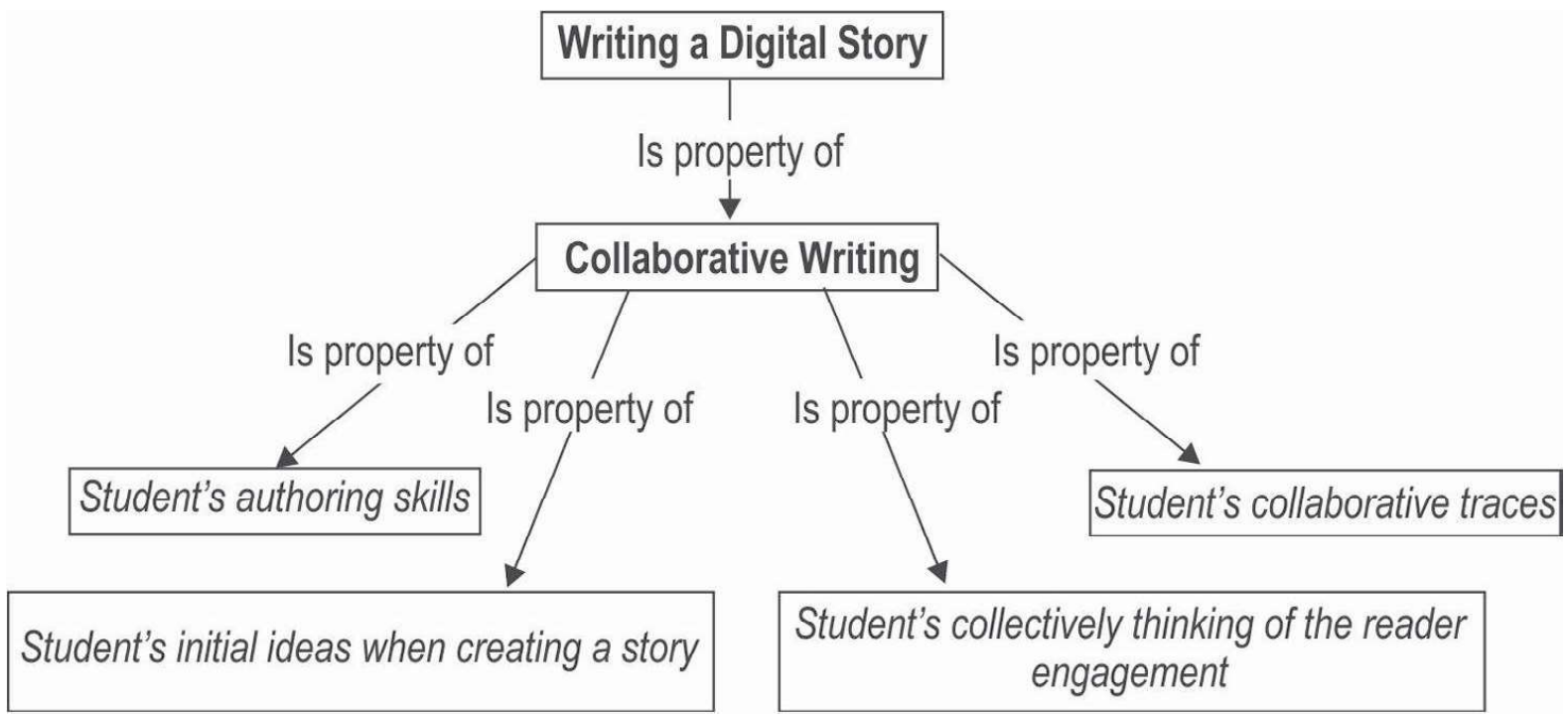

Figure 2. Collaborative writing category.

To start with the analysis of the codes, it is worth saying that authors of stories cannot start a story if they do not have an idea in mind of the topic to be worked. Hence, the authors of stories, in this case, the student participants, were authentic writers as they had an initial idea or ideas in mind about the topic of their writings. The code was named "students' initial ideas when creating a story." Excerpt number 1 is an example of that.

Excerpt 1: Interview of the students' group about the story writing process. Question 4: What were the main problems you had when creating the story?

\begin{tabular}{|l|l|}
\hline \multicolumn{1}{|c|}{ Original version } & \multicolumn{1}{c|}{ English } \\
\hline "Si fue como si porque en la primera nosotros & "At first, we wanted to produce some videos \\
quisimos hacer como videos de "YouTube" por & to publish in YouTube. We wanted to \\
decirlo así, subir algo narrar la historia, pero no & narrate a story. We didn't want to tell a story \\
hablar ni expresarnos ni contar un cuento por & or tell a fable, but we wanted to narrate a \\
decir así como fabula o algo narrativo. No. Sino & short movie about our lives, or something \\
hacer la narración de una película como de nuestras & like that." Excerpt P1: 24. Student 1. \\
vidas y esas cosas." Excerpt P1:24. Student 1. & \multicolumn{1}{|c}{} \\
\hline
\end{tabular}

This first excerpt shows that the students took elements from their experiences and put them into practice, elements from what they see, know, and use every day. Not only did they think about creating a story but also they wanted to post their lives in one. Also, they had an idea of the tool to be worked because they mentioned "YouTube," which is a big reference to create or post digital videos, tutorials, and stories. 
Indeed, the sub-category of "students" authoring skills" emerged along the process that the students faced to produce a piece of writing. Excerpt 2 exemplifies how participants started to contribute all together when creating the story. This excerpt was taken from an interview done of the whole group at the end of the process. Raimes (1983) claims that a "composition means expressing ideas, conveying ideas" (p. 261). Hence, as the teacher-researcher, I never imposed a topic; the students were able to choose and create their stories in a free manner.

Excerpt 2: Interview. Question 1: How did you as a group decide what to write about?

Describe that process.

\begin{tabular}{|l|l|}
\hline \multicolumn{1}{|c|}{ Original version } & \multicolumn{1}{c|}{ English } \\
\hline $\begin{array}{l}\text { Después decidimos que era de terror, fuimos } \\
\text { complementando la historia hasta llegar a un } \\
\text { punto donde ya dijimos que pues el tema de } \\
\text { terror nos pareció buena idea ese tema y nos } \\
\text { quedamos con ese. [Excerpt P3:6. Student 1] }\end{array}$ & $\begin{array}{l}\text { Later, we decided that we wanted to tell a } \\
\text { horror story. We mentioned some ideas until } \\
\text { we reached a point to decide that a horror } \\
\text { story seemed a good idea; so we chose it. }\end{array}$ \\
\hline
\end{tabular}

When taking decisions, the students talked about social issues, globalization, and lifestyles although choosing the topics was relevant in their authoring process. One important aspect was that they were aware of the reader engagement. This is because they were looking for some topics that motivate others to read their story; that is when the following code emerged: "Students' collectively thinking of the reader engagement." Excerpt 3 and 4 were taken from the interviews done at the middle of the implementation.

Excerpt 3: Interview open ended questions of a students' group at the end of the process.

Question 1: How did you as a group decide what to write about? Describe that process.

\begin{tabular}{|l|l|}
\hline \multicolumn{1}{|c|}{ Original version } & \multicolumn{1}{|c|}{ English } \\
\hline Decidimos como hacer una historia que hiciera como & We decided to create a story to \\
más que entender desde las pequeñas generaciones & help young generations (children) \\
que son los niños, pues le podrían ir cuidando & to understand how to take \\
el medio ambiente. [Excerpt P1:1. Student 1] & care of the environment. \\
\hline
\end{tabular}

Excerpt 4: Interview of the students' group about the story writing process. Question 2:

Who wrote the script?

\begin{tabular}{|l|l|}
\hline \multicolumn{1}{|c|}{ Original versión } & \multicolumn{1}{c|}{ English } \\
\hline Que fuera que escribiéramos algo así como lo & \\
de la película, y para pues que era una historia & We wanted to write a real story for a \\
real, y aparte, al final había una moraleja, que las & short movie with a moral: stay humble, \\
personas no deben perder su humildad por más & no matter how much you prosper. \\
de que prosperen. [Excerpt P31:5. Student 3] & \\
\hline
\end{tabular}


The above excerpts support Myers and Beach's (2004) ideas about literacy practices, in the sense that the students were not only creating a story by themselves but thinking about how the story was going to be read by someone else and how it could be an example for a community (p. 262). In addition, this idea is similar to Mei and Griffith's (2014) view about collaborative writing because it enhances "critical thinking [...] and knowledge construction" (p. 303). Accordingly, being read has to do with a cognitivist theory mentioned by Johns (1990), who claims that writers become more mature when they write for someone else, moving from "writer based... to... reader based" (p. 30). Thus, the participating students were able to create a story from a free topic by thinking about the reader engagement rather than a final score.

Another aspect that was pillar in the writing process was the "students' collaborative traces." Next, Excerpt 5 presents learner roles when creating the digital stories. Here, the students were able to differentiate their own skills from others' and to contribute to the whole process of writing a digital story according to their abilities. Thus, creating a digital story and writing it includes not only being a writer but also an artist, to combine multimodal texts in one. The students' insights, as the following one, can exemplify better the last idea. The excerpt was taken from a group at the end of the implementation.

Excerpt 5: Interview of the students' group about the story writing process. Question 3: As a group, how was the script parts written? How did you divide the work?

\begin{tabular}{|l|l|}
\hline \multicolumn{1}{|c|}{ Original version } & \multicolumn{1}{c|}{ English } \\
\hline $\begin{array}{l}\text { Eh, por ejemplo, la persona que más tenía como } \\
\text { más imaginación referente, no se a un diálogo, } \\
\text { entonces empezó a escribir el guion. La persona } \\
\text { que manejó más imaginación para atrapar a } \\
\text { las personas fue la que hizo la hipnosis, eh, la } \\
\text { persona pues que tenía más creatividad pues hizo } \\
\text { la parte artística. [Excerpt P2:4. Student 3] }\end{array}$ & $\begin{array}{l}\text { Eh, for example, the person who was } \\
\text { more creative writing dialogues wrote the } \\
\text { script; the person who was more creative to } \\
\text { engage people in it was the one in charge } \\
\text { of the 'hypnosis, and the most creative } \\
\text { person was in charge of the artistic issues. }\end{array}$ \\
\hline
\end{tabular}

This Excerpt 5 shows the way some of the students were aware when creating the stories. The excerpt mentions the way they divided some specific tasks such as writing a script, the artistic part, and doing the abstract.

Category 2, learning awareness. This category presents the students' insights about their learning process in terms of writing and the factors that influence them in the process of creating a story. The sub-categories that belong to "learning awareness" are students' agency in the creative process and collective voice (see Figure 3 below). These sub-categories show 
the students' perceptions and feelings in terms of knowing about new tools and ways of collaborating among themselves.

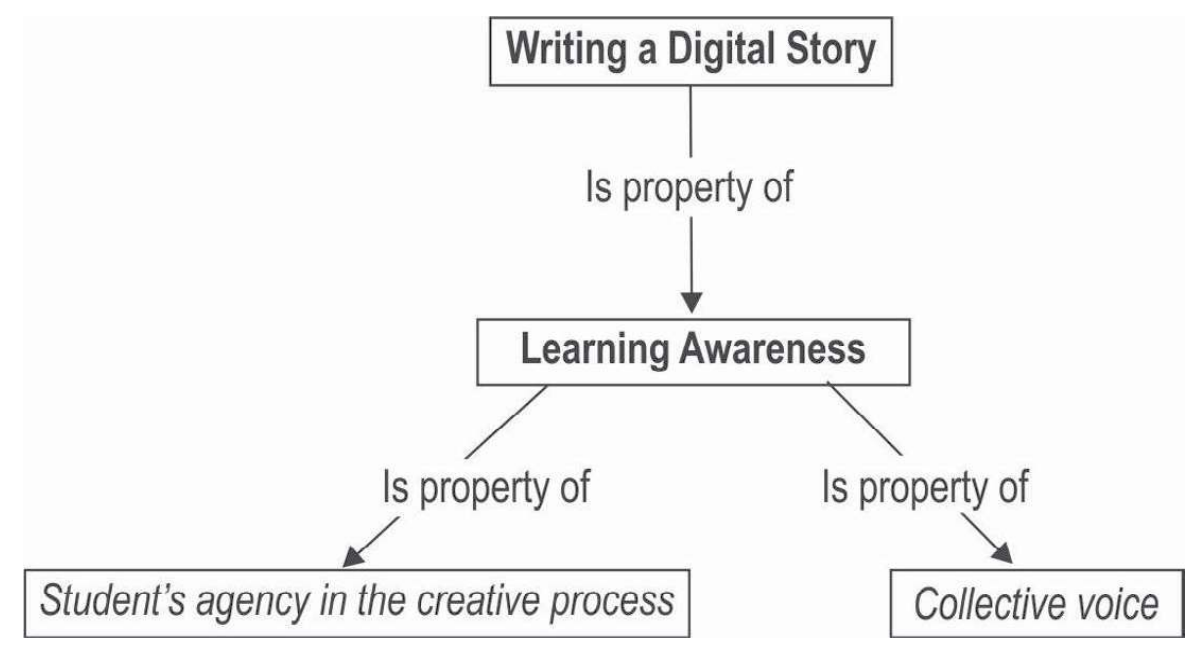

Figure 3. Learning awareness category.

The following code, "students' agency in the creative process," has to do with the students' strengths and weaknesses when creating the stories. This code also bears a close relation to the negotiation process in which the students were involved. This subcategory shows changes in the students' attitudes and weaknesses, trying to improve their final products and contributing to the group. As an example of this, Excerpt 6 was taken from an interview done with a group of the students.

Excerpt 6: Interview of a students' group about the story writing process.

Question 8: At the end of the process, what do you think the difference is between the two stories you created?

\begin{tabular}{|l|l|}
\hline \multicolumn{1}{|c|}{ Original version } & \multicolumn{1}{c|}{ English } \\
\hline $\begin{array}{l}\text { Pues la primera [historia] nos dio como más } \\
\text { experiencia ya como en manejar algunos programas, } \\
\text { digamos el ambiente en que vamos a grabar las } \\
\text { voces, hacer las cosas antes de planear de pronto } \\
\text { para que no nos quede digamos todo a última } \\
\text { hora y que por el afán sí que nos salga mal, hacer } \\
\text { las cosas con dedicación y pues de esta manera } \\
\text { nos salga mejor todo [Excerpt P2:27. Student 3] }\end{array}$ & $\begin{array}{l}\text { After writing the first story, we had } \\
\text { more experience about using programs } \\
\text { to record our voices. We planned in } \\
\text { advance to avoid doing everything at } \\
\text { the last minute and to prevent making } \\
\text { mistakes. We wanted to do things with } \\
\text { dedication, thus, everything goes well. }\end{array}$ \\
\hline
\end{tabular}

This opinion shows the students' processes when creating the stories, the participation and investment they experienced. The students, first, had an idea about what they wanted to 
write. That stage is an initial writing stage, or pre-writing, in which the author takes decisions about the purpose of their constructions. Regarding this process, the following code "collective voice," shows the evolution gained during the whole creative stage. The students passed from taking decisions to constructing their stories collectively. Considering Guasch et al. (2013), collaborative writing emerges from different factors as the number of elements as ideas, critical thinking, opinions, and different interactions presented during the process (p. 325). In that respect, before starting the digital part, the students walked through the process of discussing, sharing, giving opinions, and negotiating meaning to create a final script. In addition, they said that they had had the opportunity not only to learn English but also to develop some skills when looking for information. They concluded that they had strengthened some attitudes towards language learning.

In addition, "collective voice" shows the agreements and disagreements that the students had throughout the implementation. The way they assumed the discourse by taking over the representations of the group in the Spanish first person plural form (-mos, nos, os) expresses the students' voices about the decisions taken and the different challenges they faced across the implementation. The main characteristics of this code are, first, that the student participants manifested writing with a purpose. They also evidenced reaching agreement in writing ideas and that collective voice was shaped by the ideas and self-identification shown in the process of co-construction of the story. This also has a strong relation to the micropolitical theories of learning that occur as a reason of the social interaction and negotiation of meaning. Furthermore, (we can say) the collective voice explains the construction of a literacy practice in the classroom. Excerpt 7 exemplifies it. This was taken when interviewing the students at the end of the study.

Excerpt 7: Interview of a students' group at the end of the process using open-ended questions. Question 1: How did you as group decide what to write about?

Describe that process.

\begin{tabular}{|l|l|}
\hline \multicolumn{1}{|c|}{ Original version } & \multicolumn{1}{c|}{ English } \\
\hline $\begin{array}{l}\text { Fue basándonos en las ciudades que pensábamos } \\
\text { que nuestros compañeros tenían. Pensamos que } \\
\text { todos lo demás lo iban a hacer de un tema fácil, } \\
\text { como digamos lo es digamos el amor, o temas que } \\
\text { no son necesarios usar tanto sonido o imágenes } \\
\text { diferentes. Entonces buscamos el tema de terror } \\
\text { para poder hacer, o sea, hacer un trabajo más } \\
\text { elaborado y mejor hecho [Excerpt P3:3. Student 3] }\end{array}$ & $\begin{array}{l}\text { We took into account the cities that we } \\
\text { that others were going to choose an easy } \\
\text { topic like love or topics that do not require } \\
\text { the of sounds or different images. } \\
\text { Then, we chose the topic of horror to } \\
\text { make a better and more complex work. }\end{array}$ \\
\hline
\end{tabular}


The above exemplifies the way the students were working in groups for creating digital stories. They were rationalizing the process in terms of the collective construction. In addition we saw, for the students, how selecting a topic implied not only a simple decision but a democratic and analytical revision of their own ideas.

Category 3, literacy practices. The final category shows the way literacy practices are seen and worked by the students along the project. Figure 4 below presents the relation that media literacy and language development have with the creation of a story. This figure also presents the way the students fostered their literacy practices in a foreign language when implementing digital tools.

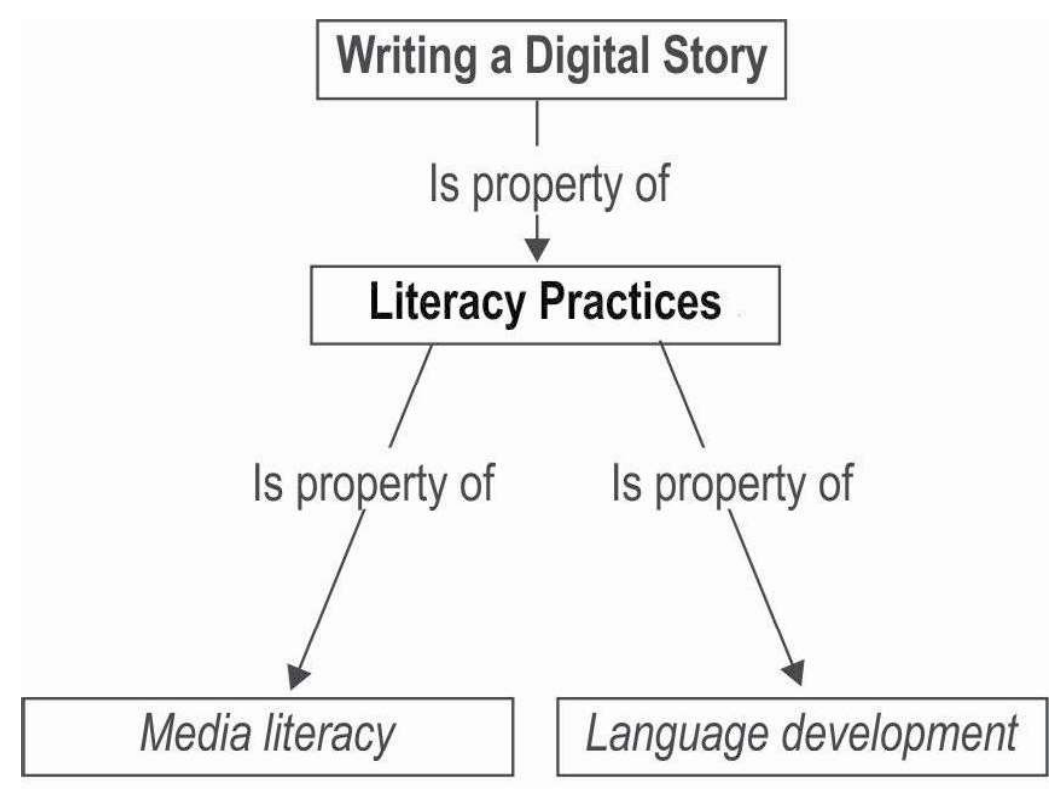

Figure 4. Literacy practices category.

Media literacy is the faculty of using the different communicative and linguistic skills in connection with a digital source. Asthana (2008) claims that "the media [...] is a world where powerful images, words and sounds create reality" (p. 130). Thus, some web pages and sources were used by the students to use images and sounds as part of the process, which means that most of the stories had images previously created, adapted, and posted according to the content of the stories. Furthermore, it has strong connection with the elements mentioned by Czarnecki (2009) about visual literacy (p. 16). These elements are clearly shown in the final products that the students mentioned in excerpts 8 and 9, for example. These excerpts were taken from interviews with different students. 
Excerpt 8: Interview of a students' group about the story writing process. Question 5: When creating the storyboarding, how did you decide on the images and sounds to be included in the story?

\begin{tabular}{|l|l|}
\hline \multicolumn{1}{|c|}{ Original version } & \multicolumn{1}{c|}{ English } \\
\hline Pues las imágenes las elegimos, pues fuimos buscando & Well, we searched in the Internet \\
pues en internet, por lo que nuestra historia pues & to choose the images because we \\
es en silueta; entonces entre todas, estuvimos & used silhouettes to tell our story. \\
eligiendo las imágenes y la que editó todo y los & We all helped to choose the images \\
unió pues fue Juana. [Excerpt P4:8. Student 2] & and Juana edited them all. \\
\hline
\end{tabular}

Excerpt 9: Student insight about his written process. Question 1: What are the positive and negative aspects of the use of digital story telling? Describe each.

\begin{tabular}{|l|l|}
\hline \multicolumn{1}{|c|}{ Original version } & \multicolumn{1}{|c|}{ English } \\
\hline Programas como "Crazy talk" son de un manejo & Programs as "Crazy talk" are very easy to \\
muy sencillo, simplemente se deben seguir los & use; you simply have to follow the steps \\
pasos que nos proponen; en los programas & that they propose. In programs as "Movie \\
como "Movie Maker" y "Sony Vegas Pro" es & Maker" and "Sony Vegas Pro," editing a \\
un poco más complejo, ya que contiene muchas & movie is a bit more complex, as it contains \\
más herramientas que se deben aprender a & many more tools to learn how to use. \\
controlar. [Excerpt P10:2. Student 2]. & \\
\hline
\end{tabular}

In the last comment, the participating student talks about the uses of different tools. In addition, more comments describe the advantages and disadvantages of using those programs. But there were also worthy ideas of collaborative learning when they decided what tools to use to carry out their project in a better way.

As media literacy talks about the ability that people have when using technology to complement their learning skills, the next comment shows how another participating student used the tools to point out the implementation of those technological elements in the construction of the stories. The excerpt was taken from a group of learners who finished their story.

Excerpt 10: Interview of a students' group about the story writing process. Question 10: When the story was submitted, did you consider that something could be missing in it?

\begin{tabular}{|l|l|}
\hline \multicolumn{1}{|c|}{ Original version } & \multicolumn{1}{c|}{ English } \\
\hline $\begin{array}{l}\text { Digamos, en la otra historia, incluso en la que } \\
\text { estamos haciendo, estamos buscando la manera } \\
\text { de poner animaciones u otra herramienta que nos } \\
\text { ayude a que no solo sean imágenes sino también } \\
\text { además la parte de video a contar la historia no } \\
\text { solo hablado. [Excerpt P27:21. Student 2] }\end{array}$ & $\begin{array}{l}\text { Let's say that, in the other story, } \\
\text { even the one we are doing, we are } \\
\text { looking for ways to put animation } \\
\text { or another tool that will help us not } \\
\text { only to use images but also video to } \\
\text { tell the story, not just to use audio. }\end{array}$ \\
\hline
\end{tabular}


The student mentioned that it was helpful to use the images and the sounds because they only have their voices. But the idea of using them was to complement the story in order to make it easy for an audience to be understood.

To conclude the data analysis, the way language was seen by the participants at the end of the implementation is important to highlight. Most of the opinions gave an account of students' experiences about creating the digital stories in their language learning process. Therefore, the code "language development" and the following excerpts support the ideas above. Excerpts 11 and 12 were taken from the students at the end of the process of writing a story.

Excerpt 11: Student insight about his written process. Question 1: What are the positive and negative aspects of the use of digital story telling? Describe each.

\begin{tabular}{|l|l|}
\hline \multicolumn{1}{|c|}{ Original version } & \multicolumn{1}{c|}{ English } \\
\hline $\begin{array}{l}\text { Esto nos anima a practicar el inglés, lo cual } \\
\text { nos ayuda a que este idioma sea más fluido en } \\
\text { nosotros pues no solo practicamos un solo }\end{array}$ & $\begin{array}{l}\text { This encourages us to practice English } \\
\text { which in turn helps us to be more fluent }\end{array}$ \\
item ${ }^{2}$ de los 5 que vemos en inglés, podemos & because not only do we practice a single \\
hablar mediante la caracterización, escribir el & item of the 5 that we see in English, but \\
guion, leer, escuchar y entender al momento de & also we can speak through characterization, \\
ver las historias. [Excerpt P11:2. Student 2] & write the script, read, listen and understand \\
\hline
\end{tabular}

Excerpt 12: Student insight about his written process. Question 1: What are the positive and negative aspects of the use of digital story telling? Describe each.

\begin{tabular}{|c|c|}
\hline Original version & English \\
\hline $\begin{array}{l}\text { Creo que esta forma de enseñar inglés es } \\
\text { muy buena ya que es algo diferente de lo } \\
\text { que estamos acostumbrados a recibir como } \\
\text { clase de inglés. Es algo más motivante hacia } \\
\text { el estudiante por que hace que investiguemos } \\
\text { más, queramos cada vez más tener mejor } \\
\text { vocabulario. [Excerpt P13:5. Student 2] }\end{array}$ & $\begin{array}{l}\text { I think this way of teaching English is very } \\
\text { good because it is something different } \\
\text { from the way we usually study in class. } \\
\text { It is something more motivating for the } \\
\text { students because it makes us investigate } \\
\text { more to have more vocabulary. }\end{array}$ \\
\hline
\end{tabular}

At the end of the implementation, the student considered that he had learnt more from the project than from the "typical class" in which the course book was used to practice

\footnotetext{
"Item" refers to the language skills worked in the syllabus by the teachers in the school e.g. reading and speaking.
} 
learning skills. Moreover, the students in general felt that, at some stages in the process, they had learned without any help when to look for information and sources for their stories. That shows a sense of autonomy ratifying that, despite being involved in collaborative work, a few of the students acquired a self-identity when working in groups.

The final excerpt below, taken from a student reflexion done at the end of the process, shows that the students liked recording their voices more than speaking in front of their classmates. Furthermore, the students started to see English in a different manner; they saw it as a language in use, not just as a requirement without sense. Finally, they used their literacy without pressure; then, they were able to improve their authoring skills and, in terms of writing, the paragraphs construction and digitalization of the stories in a foreign language.

Excerpt 13: Student insight about his written process. Question 1: What are the positive and negative aspects of the use of digital story telling? Describe each.

\begin{tabular}{|l|l|}
\hline \multicolumn{1}{|c|}{ Original version } & \multicolumn{1}{c|}{ English } \\
\hline $\begin{array}{l}\text { Cambió drásticamente la forma de aprender } \\
\text { fluidez al hablar debido a que no fue como } \\
\text { siempre, que es pararse frente de sus } \\
\text { compañeros a hablar un idioma el cual apenas } \\
\text { conocemos, y lógicamente eso va a generar una } \\
\text { presión muy alta para el estudiante. Con este } \\
\text { proyecto podíamos practicar la fluidez desde } \\
\text { la comodidad de su casa mientras grabara las } \\
\begin{array}{l}\text { voces sin ningún tipo de presión y hablara } \\
\text { más fluido. [Excerpt P21:9. Student 2] }\end{array}\end{array}$ & $\begin{array}{l}\text { It drastically changed the way to practice } \\
\text { fluency because it was not as it used to be, } \\
\text { standing in front of their classmates to } \\
\text { speak a language which we barely know. } \\
\text { Logically, that will generate a very high } \\
\text { pressure for the student. With this project, } \\
\text { I could practice fluency from the comfort } \\
\text { of my home while recording voices } \\
\text { without any pressure to speak fluently. }\end{array}$ \\
\hline
\end{tabular}

Therefore, Excerpt 13 shows that the students' ideas go beyond simple language learning because they assume that digital stories comprised a good element to be used in different subjects. This fact was exemplified in the cross-curricular relations they made. Some of the students considered more options like learning to manage new programs, autonomy, second language acquisition, and narrative skills.

\section{Conclusions}

Firstly, the student-participants had the possibility of implementing the target language for different purposes such as informing or leaving a message. For example, one group wrote about contamination in the world, another about football, and others about love and superheroes. Data showed that negotiation of meaning and content was an important element when the students created their stories. In addition, the students acquired better 
understanding of their process as writers and authors. They worried about the idea of improving from the first to the third story. When they assessed their work in terms of accuracy, content, and process, they showed that they were aware of their literacy practices, and how much these had improved by the use of the target language in each of their digital stories. Furthermore, digital story telling allowed the students to create different texts, communicate their ideas, express their thoughts and insights, and tell their stories ${ }^{2}$, not only in a written form but through images, sounds, and media texts.

Secondly, writing is a process that requires thinking about the text and reader (Johns (1990, p. 27). That process was part of this study because in almost all the stories created, the students were thinking about the reader's engagement. That means that the students were worried about the readers' opinions and beliefs, then they decided to develop different stories to be read and understood by any kind of readers.

Thirdly, collaborative work is defined by Salinas (2014) as "essential in any learning context because we are social human beings who construct knowledge together" (p. 33). Working by groups was an important element in the development of the students' literacies and in the creation of digital stories. Thus, the students constructed their writings by negotiating and giving ideas in the process. Moreover, they assumed certain roles according to their abilities. For example, some students were skilled in the use of digital tools; others were good at writing; others at editing. All members of the group intervened in the process. Then writing and speaking were not isolated tasks.

\section{Pedagogical Implications}

Mainly, feedback plays an important role in the writing process and in the creation of digital stories. This is part of the roles that English language teachers should play when their students carry out writing activities. This feedback can have a focus on both linguistic aspects and contents. Furthermore, beginners need an outline that guides them throughout the construction of their texts. This could be a description of writing stages or simply a number of parameters to follow. This is an initial stage to make students better writers.

This research project and the students' comments were a great opportunity to identify their likes, dislikes, and expectations about the curriculum, not only in the English language field but also in other subjects. I consider digital story telling as part of the curriculum

\footnotetext{
As an example, different artifacts collected are available at:

https://www.youtube.com/watch?v=NCEY-5Uu9Tw\&feature=youtu.be

https://www.youtube.com/watch?v=bl3v5iQX3yo\&list=UU0my6nUkb6xPoTP2Aze6Ahw

https:/ www.facebook.com/video.php?v=410402805749829\&set=o.176054915916238\&type=2\&theater)
} 
in many schools because of the different possibilities it offers. Including technological tools in the classroom and curriculum has demonstrated that this is a means of motivation for students when writing and developing their literacy. In the current study, the use of technological tools helped the participating students improve their coherence and cohesion when expressing their ideas. Also, they started to use more vocabulary in their final scripts. However, the writing process should be continual since students are always learning the language.

Some additional examples of motivation when implementing digital tools were the research projects carried out by Lopez (2011), Valderrama (2012), Prada (2011), Clavijo et al. (2011) and Vera et al. (2011). All agree on the importance of integrating ICTs to the curriculum of language learning because people around the world are living in a digital era. Therefore, they need language teachers to focus on the implementation of digital instruments in teaching. What I identified with the students' attitudes and opinions in the current study was that digital storytelling could allow language teachers to motivate its use and take advantage of it to change the explanations and the involvement that students may have in class somehow.

\section{References}

Aguirre, A. (2010). Writing hyperstories collaboratively for an authentic audience (Unpublished master thesis). Universidad Distrital Francisco José de Caldas, Bogotá, Colombia.

Alvermann, D., \& Hagood, M. (2000). Critical media literacy: Research, theory, and practice in "new times". The Journal of Educational Research, 93(3), 193-205.

Asthana, S. (2008). Young people, new media, and visual design: An Exploratory Study. Youth Media Reporter, Academic issue, 129-137.

Alavi, M. (1994). Computer-mediated collaborative learning: An empirical evaluation. MIS Quarterly, 18(2), 159-174.

Bayon, V., Wilson, J., Stanton, D., \& Boltman, A. (2003). Mixed reality storytelling environments. Virtual Reality, 7, 54-63.

Bruffee, K. (1984). Collaborative learning and the "conversation of mankind". College English, 46(7), 635-652.

Clavijo, A., Quintana, A., Quintero, L., (2011). Enseñanza del inglés y medios digitales: nuevos retos y posibilidades para la escuela. Bogota, Colombia: Editorial UD.

Creswell, J. (2014). Research design: Qualitative, quantitative, and mixed methods approaches (4 ${ }^{\text {th }}$ Ed.). Los Angeles: Sage Publications.

Cross, D. (2007). Developing writing skills: A practical handbook of language teaching. Phoenix: Prentice Hall.

Crystal, D. (2010). A little book of language. USA: Yale University Press. 
Czarnecki, K. (2009). How digital storytelling builds 21 st century skills. Library Technology Reports, 15-19.

Guasch, T., et al. (2013). Effects of feedback on collaborative writing in an online learning environment. Distance Education, 34(3), 324-338.

Johns, A. M. (1990). L1 Composition theories: Implications for developing theories of L2 composition. In B. Kroll (Ed.), Second language writing (pp. 24-36). Cambridge: Cambridge University Press.

Kenny, R. (2008). Digital narrative as a change agent to teach reading to media-centric students. International Journal of Social Science, 2(3), 187-195.

Kellner, D., \& Share, J. (2005). Toward critical media literacy: Core concepts, debates, organizations, and policy. Discourse Studies in the Cultural Politics of Education, 26(3), 369-386.

Lankshear, C., \& Knobel, M. (2004). A handbook for teacher research (1st Ed.). UK: McGraw-Hill International.

Lopez, S. (2011). Weblogs: a way to promote digital literacies skills and EFL writing (Unpublished master thesis). Universidad Distrital Francisco José de Caldas, Bogotá, Colombia.

Malkawi, R., \& Davies, P. (2012). Integration of multi-media technologies to facilitate reflection and learning, particularly in the area of digital storytelling. In Proceedings of the International Conference on Education and e-Learning Innovations (ICEELI), Sousse, Tunisia, 1-3 July 2012.

Mei, L., \& Griffith, P. (2014). Impacts of online technology use in second language writing: A review of the literature. Reading Improvement, 51(3), 303-312.

Myers, J. (2006). Literacy practices and digital literacies: A commentary on Swenson, Rozema, Young, McGrail, and Whitin. Contemporary Issues in Technology and Teacher Education, 6(1), 61-66.

Myers, J., \& Beach, R. (2004). Constructing critical literacy practices through technology tools and inquiry. Contemporary Issues in Technology and Teacher Education, 4(3), 257-268.

Nisha, M. (2012). Research sampling. Indian Streams Research Journal, 2(10), 16-33.

Prada, A. (2011). A window to social voices: Argumentative writing through digital artifacts (Unpublished master thesis). Universidad Distrital Francisco José de Caldas, Bogotá, Colombia.

Raimes, A. (1983). Anguish as a second language? Remedies for composition teachers. In A. Freedman, I. Pringle, \& J. Yalden (Eds.), Learning to write: First language/second language (pp. 258-272). London: Longman.

Rojas, G. (2011). Writing using blogs: A way to engage Colombian adolescents in meaningful communication. Profile: Issues in Teachers' Professional Development, 13(2), 11-27.

Salinas, Y. (2014). Collaborative project work development in a virtual environment with low-intermediate undergraduate Colombian students. Profile: Issues in Teachers' Professional Development, 16(1), 29-48.

Vaismoradi, M. (2013). Content analysis and thematic analysis: Implications for conducting a qualitative descriptive study. Nursing and Health Sciences, 15, 398-405. 
Valderrama, D. (2012). EFL learners' investment in online digital literacies (Unpublished master thesis). Universidad Distrital Francisco José de Caldas, Bogotá, Colombia.

Vera, E., Perez, D., \& Olaya, A. (2011). Hacia una perspectiva de desarrollo profesional mediado por TIC para docentes de inglés. Bogotá, Colombia: Universidad Pedagógica Nacional.

White, R., \& Arndt, V. (1991). Process writing (1 ${ }^{\text {st }}$ Ed.). London: Longman. 